\title{
IMLEMENTASI KEBIJAKAN REVITALISASI PASAR TRADISIONAL SARIJADI OLEH PD. PASAR BERMARTABAT KOTA BANDUNG
}

\author{
Oleh \\ Yuyun Mulyati1), Ani Surtiani2) \\ 1)Dosen Administrasi Negara Universitas Al-Ghifari; ${ }^{2}$ Dosen Administrasi Publik STIA Bandung \\ email:mulyati.yuyun@gmail.com
}

\begin{abstract}
ABSTRAK. Penelitian ini bertujuan untuk menganalisis dan menggambarkan aktivitas implementasi kebijakan revitalisasi Pasar Tradisional Sarijadi oleh PD. Pasar Bermartabat Kota Bandung yang meliputi organization, interpretation dan application. Penelitian ini menggunakan pendekatan kualitatif dengan metode deskriptif analisis. Teknik pengumpulan data dilakukan dengan wawancara mendalam, observasi dan studi kepustakaan. Hasil penelitian menunjukkan aktivitas organization belum didukung sumber daya manusia dan sarana prasarana yang sesuai dengan kebutuhan, sedangkan sumber dana sudah cukup memadai. penetapan pasar tematik sayuran organik untuk Pasar Sarijadi dan sosialisasi langsung kepada pedagang serta studi banding yang diikuti oleh para pedagang dan pegawai serta Direksi PD. Pasar bermartabat Kota Bandung merupakan metode pengorganisasian. Aktivitas interpretation terkait program kerja dan kegiatan revitalisasi belum didukung dengan pedoman dan arahan pencapaian target ke depan karena belum ditetapkan Rencana Strategis. Sedangkan aktivitas application Implementasi Kebijakan Revitalisasi Pasar Tradisional Sarijadi oleh PD. Pasar Bermartabat Kota Bandung terkait penyediaan layanan sudah menggunakan teknologi informasi untuk layanan pembayaran retribusi dan pengurusan Surat Tanda Tempat Usaha (STTU), juga promosi untuk penawaran sewa ruang dagang. Kesimpulan Penelitian menunjukkan bahwa Implementasi kebijakan revitalisasi Pasar Tradisional Sarijadi oleh PD. Pasar Bermartabat Kota Bandung belum berjalan sebagaimana mestinya. Saran penelitian adalah perlu segera ditetapkan Rencana Strategis, perlu pelaksanaan pendidikan dan pelatihan pegawai serta penambahan sarana prasarana.
\end{abstract}

Kata Kunci: implementasi kebijakan, revitalisasi, pengorganisasian, interpretasi dan aplikasi

ABSTRACT. This study aims to analyze and describe the implementation activities of revitalization policy of Traditional Market Sarijadi by PD. Pasar Bermartabat of Bandung City which includes organization, interpretation and application. This research uses qualitative approach with descriptive method of analysis. Data collection techniques were conducted with in-depth interviews, observations and literature studies. The results of the study indicate that the organization has not been supported by human resources and facilities in accordance with needs, while the funds are sufficient. Establishing a thematic organic vegetable market for Sarijadi Market and direct socialization to higher education and comparative study followed by traders and employees and Directors of PD. Pasar Bermartabat of Bandung city is an organizing method. Interpretation of activities related to work programs and revitalization activities has not been supported by future guidelines and targets because no Strategic Plan has been determined yet. While the application activity of the Implementation of Sarijadi Traditional Market Revitalization Policy by PD. Pasar Bermartabat of Bandung City associated with the service has been using information technology for levy and maintenance services of Business Registration Letters and promotions for rental offerings. Research report on the Implementation of Sarijadi Traditional Market Revitalization Policy by PD. Pasar Bermartabat Bandung City has not yet run. Research suggestions need to be established immediately in the Strategic Plan, training and training facilities are needed, the addition of infrastructure.

Keywords: policy implementation, revitalization, organization, interpretation and application 


\section{PENDAHULUAN}

Kota Bandung sebagai ibukota Provinsi Jawa Barat memiliki potensi yang sangat besar dalam bidang perdagangan. Kota Bandung merupakan daerah tujuan wisata, yang berpotensi terhadap berkembang. sehingga potensi pariwisata semakin mendukung potensi di bidang perdagangan. Undang-Undang (UU) No.

23 Tahun 2014 tentang Pemerintah Daerah telah memberikan ruang kepada Pemerintah Kota Bandung untuk menggali dan mengembangkan potensi Pendapatan Asli Daerah (PAD), antara lain menetapkan kebijakan-kebijakan termasuk kebijakan di bidang perdagangan yang mendukung penguatan UKM.

Saat ini, di Kota Bandung terdapat sekitar kurang lebih 3000 UKM, di antaranya bergerak di pasar-pasar tradisional, di lain pihak pasar-pasar modern terus meningkat seiring dengan perkembangan gaya hidup masyarakat yang menginginkan tempat belanja yang bersih dan nyaman, oleh karena itu pasar tradisional perlu ditingkatkan daya saingnya, oleh karena pasar tradisional menjadi sumber usaha masyarakat kecil yang perlu dilindungi pemerintah dan dikembangkan.

Pengelolaan Pasar Tradisional di Kota Bandung dilaksanakan oleh PD Pasar Bermartabat Kota Bandung dengan motto "SAE", sesuai fungsi pelayanan publik SAE artinya Santun, Akuntabel dan Efisien. Visi yang diemban Perusahaan adalah "Menjadi perusahaan pengelola perpasaran yang mandiri dan berkelas dunia." Salah satu pasar yang telah direvitalisasi dan mendapat perhatian warga asing adalah Pasar Baru. PD. Pasar Bermartabat merupakan Badan Usaha Milik Daerah Pemerintah Kota Bandung yang melaksanakan pelayanan umum dalam bidang pengelolaan property dan pasar, membina pedagang pasar, ikut membantu stabilitas harga dan kelancaran distribusi barang dan jasa.

Dasar hukum pembentukan PD. Pasar Bermartabat Kota Bandung adalah Peraturan Daerah Kota Bandung Nomor 15 Tahun 2007 tentang Perusahaan Daerah Pasar Bermartabat Kota Bandung. Dalam perkembangannya, Peraturan Daerah Nomor 15 tahun 2007 disesuaikan sehingga ditetapkan Peraturan Daerah Kota Bandung Nomor 02 Tahun 2012 tentang Perusahaan Daerah Pasar Bermartabat Kota Bandung. Kemudian dasar hukum pembentukan PD. Pasar Bermartabat Kota Bandung mengacu kepada Peraturan Daerah Kota Bandung Nomor 08 Tahun 2013 tentang Perubahan Atas Peraturan Daerah Kota Bandung Nomor 02 Tahun 2012. Hal tersebut sesuai dengan tujuan Kebijakan Revitalisasi Pasar Kota Bandung yang tertuang dalam Keputusan Walikota Bandung Nomor. 511.2/Kep. 155 Huk/2006 Tentang Revitalisasi Pasar. Kebijakan tersebut merupakan kebijakan yang mengacu kepada Pasal 8 ayat (3) Peraturan Menteri Perdagangan RI Nomor 70/M-DAG/PER/12/2013 tentang 
Pedoman Penataan dan Pembinaan Pasar Tradisional Pusat Perbelanjaan dan Toko Modern yang menyatakan :"peningkatan daya saing sebagaimana dimaksud pada ayat (2) adalah peremajaan atau revitalisasi bangunan pasar tradisional."

PD. Pasar Bermartabat Kota Bandung didirikan dengan maksud dan tujuan sebagai berikut:

1. Menyediakan pelayanan kepada masyarakat sesuai dengan lingkup usahanya.

2. Meningkatkan Pendapatan Asli Daerah.

3. Turut serta melaksanakan pembangunan daerah dan menunjang kebijakan program pemerintah di bidang ekonomi.

4. Pembangunan di bidang pengelolaan pasar serta dibidang usaha barang dan jasa yang berkaitan dengan pengelolaan pasar dengan menerapkan prinsip-prinsip tata kelola perusahaan yang baik.

5. Memanfaatkan sumber daya dan aset yang dimiliki Perusahaan Daerah guna meningkatkan produktivitas barang dan jasa yang bermutu tinggi.

(Keputusan Walikota Bandung Nomor. 511.2/Kep. 155 Huk/2006)

Pengelolaan pasar di Kota Bandung perlu dilakukan karena pasar tradisional di Kota Bandung masih menjadi salah satu tempat yang menunjukkan sisi keindahan kehidupan sosial masyarakat Kota Bandung (Kamil, 2015). Kehidupan pasar tidak akan pernah berhenti, sedangkan kondisi pasar yang tersebar di setiap Kecamatan dan Kelurahan sangat tidak nyaman, sehingga para ibu rumah tangga yang sebagian besar merupakan konsumen pasar tersebut, terpaksa harus merasakan bau menyengat dari tumpukan sampah, percikan air hujan dan kubangan air harus dialaminya.

Mengacu kepada PERDA Kota Bandung Nomor 19 Tahun 2001 tentang Pengelolaan Pasar, Walikota Bandung menetapkan kebijakan mengenai Revitalisasi Pasar melalui Keputusan Walikota Bandung Nomor 511.2/Kep.155Huk/2006 tentang Revitalisasi Pasar. Revitalisasi Pasar Kota Bandung dilaksanakan oleh PD. Pasar Bermartabat. PD. Pasar Bermartabat adalah perubahan organisasi pengelola pasar, yang sebelumnya dikelola oleh Dinas Pasar Kota Bandung.

Kebijakan revitalisasi pasar Kota Bandung merupakan upaya pemerintah Kota Bandung dalam meningkatkan fungsi dan potensi pasar tradisional sehingga dapat berdaya saing dan tidak kalah dengan keberadaan pasar modern. Rencana revitalisasi Pasar yang murni dilakukan oleh PD. Pasar Bermartabat meliputi 7 pasar tradisional, yaitu : Pasar Sarijadi, Pasar Sederhana, Pasar Kosambi, Pasar Cihaurgeulis, Pasar Palasari, Pasar Wastukencana, dan Pasar Cijerah. (Sumber: PRonline,2016)

Sampai saat ini, revitasilasi pasar tradisional di Kota Bandung oleh PD Pasar Bermartabat belum dapat dilaksanakan 
sesuai target yang telah ditetapkan. Selain permasalahan teknis di lapangan, berdasarkan hasil studi pendahuluan, diketahui bahwa PD. Pasar Bermartabat memiliki masalah sumber daya manusia. Sampai tahun 2008 PD. Pasar Bermartabat memiliki sumber daya manusia yang berstatus Pegawai Negeri Sipil dengan memiliki pengalaman yang baik dalam mengelola pasar, yang sebelumnya merupakan pegawai pada Dinas Pasar Kota Bandung. Namun Kebijakan Pemerintahan Daerah yang menetapkan bahwa PD. Pasar Bermartabat harus memiliki sumber daya manusia tersendiri, sehingga pegawai lama harus dikembalikan kepada pemerintah daerah Kota Bandung. Kenyataan ini mengakibatkan terjadi kekosongan pegawai di PD. Pasar Bermartabat dalam beberapa bulan hingga akhirnya baru di tahun 2015 dilengkapi oleh pegawai baru dengan pengalaman yang terbatas. Kondisi dikembalikannya pegawai PD. Pasar Bermartabat ke Pemerintah Daerah Kota Bandung tidak sempat memberikan kesempatan untuk transfer knowledge kepada pegawai baru. Oleh karena itu kondisi pegawai saat ini jauh dari kualitas yang diharapkan.

$\begin{array}{cc}\text { Meskipun ada permasalahan } \\ \text { internal organisasi, } & \text { PD. Pasar }\end{array}$

Bermartabat dituntut untuk tetap melaksanakan program revitalisasi pasar tradisional di Kota Bandung. Untuk melaksanakan revitalisasi pasar perlu dilakukan relokasi pasar, karena revitalisasi pasar dimulai dengan proses pengembangan fisik pasar dengan membongkar bangunan fisik pasar lama. Berdasarkan hasil studi pendahuluan, hal ini terjadi karena terhambat mencari tempat untuk merelokasi pedagang dari pasar yang akan direvitalisasi. Hambatan lain adalah proses administratif berkenaan dengan pengurusan sertifikat dan ljin Mendirikan Bangunan (IMB). Kenyataan ini terjadi, menurut Wali Kota Bandung, karena para pelaksana kebijakan belum melaksanakan tugasnya dengan baik. Kondisi belum terlaksananya kebijakan revitalisasi pasar mengakibatkan dana revitalisasi yang dianggarkan oleh Pemerintah kota Bandung pada tahun 2015 sebesar Rp. 86 Milyar, baru bisa terserap sebesar 15 Milyar. (Kamil, 2015).

Revitalisasi pasar tradisional di Kota Bandung oleh PD. Pasar Bermartabat dimulai dengan Revitalisasi Pasar Sarijadi. Hal ini karena permasalahan Pasar Sarijadi secara teknis di lapangan, terkait relokasi pedagang dan IMB dapat diselesaikan terlebih dahulu. Revitalisasi Pasar Sarijadi oleh PD. Pasar Bermartabat yang direncanakan mulai tahun 2014 dan selesai tahun 2015, namun pada kenyataannya mengalami kendala sehingga baru dapat dilakukan pada tahun awal 2016. Pasar Sarijadi akan direvitalisasi dibangun dengan konsep pengelolaan secara modern yang akan dibangun di atas lahan $3.538,34 \mathrm{~m} 2$, 
dengan bangunan seluas lebih kurang $5.200 \mathrm{~m} 2$, yang terdiri dari 3 lantai yaitu dialokasikan untuk fasilitas ruang dagang sebanyak 194 unit, 42 unit di lantai dasar diperuntukan untuk komoditi basahan dan sisanya 152 unit untuk komoditi keringan. Karena berdekatan dengan lokasi Kampus Politeknik Bandung dan Politeknik Pos Indonesia, maka Pasar Sarijadi dilengkapi fasilitas tambahan, yaitu sarana olah raga lapangan futsal, area foodcourt, dan hunian kos-kosan sebanyak 16 kamar.

Pada mulanya, Pasar Sarijadi didirikan pada tahun 1985 di atas tanah seluas

$3.538,34 \mathrm{~m} 2$, dengan status tanah adalah hibah dari Perum Perumnas dan dibiayai dari dana Inpres sebesar Rp. 77.527.000,- pada saat itu, pasar dibangun dengan 110 ruang dagang, yang terdiri dari 90 kios dan 20 meja. Namun dalam perjalanannya, kondisi pasar Sarijadi hanya diisi oleh 19 pedagang yang aktif, sebagian besar ruang dagang dibiarkan kosong dan tidak digunakan, sehingga kondisi pasar menjadi rusak dan tidak representative dan akhirnya masyarakat Sarijadi dan sekitarnya memilih pasar swasta Sari Rahayu yang berlokasi di daerah Cibogo. ( Sysadmin, 2014). Mengacu kepada latar belakang di atas, nampak pelaksanaan kebijakan revitalisasi pasar tradisional Sarijadi Oleh PD. Pasar Bermartabat Kota Bandung belum mencapai tujuannya, sehingga perlu dikaji lebih dalam.
TINJAUAN PUSTAKA

\section{Konsep Kebijakan Publik}

Kebijakan publik merupakan kegiatan bertindak atau tidak bertindak oleh pemangku kewenangan publik yang bertujuan untuk menyelesaikan permasalahan. Hal ini sesuai dengan pendapat Pal (1990:1) yaitu : " public policy will be defined as a course of action or inaction chosen by public authorities to address a given problem or interrelated set of problems". Lebih jauh Michael Moran dkk., menjelaskan :

These definitions were intended to give a signal to particular audiences, and are incomplete. For instance, "policy" may relate to the principles and priorities which a government adopts in relation to an issue, and not to their translation into action: see above. And not all policies are about bringing about change. In some cases the objective of policy is continuity (Moran, dkk, 2006 :5).

Dari pengertian tersebut, kebijakan dapat dihubungkan dengan prinsip-prinsip dan prioritas yang diadopsi pemerintah ke dalam suatu isu dan tidak diterjemahkan ke dalam bentuk tindakan, tidak semua kebijakan membawa perubahan. Dalam beberapa kasus, sasaran kebijakan adalah berkelanjutan. Jadi kebijakan publik diasumsikan dilakukan oleh pemerintah sebagaipengambil keputusan.

Kebijakan publik pada dasarnya menekankan pada permasalahanpermasalahan yang ada pada publik, lalu dilakukan pembahasan, dikonstruksikan, 
didefinisikan serta diusahakan untuk diangkat menjadi sebuah agenda kebijakan.

\section{Proses Kebijakan Publik}

Kebijakan publik terdiri dari beberapa tahapan proses. Parsons (1995:77) mengemukakan bahwa ada 7 tahapan proses kebijakan yaitu : "Problem Identification; Problem definition; Identifying alternative responses/solutions; Evaluation of Options; Selection of policy option; Implementation; Evaluation". $\begin{array}{lll}\text { Sedangkan } & \text { Dye } & (1992: 25) \\ \text { mengemukakan } & \text { tentang } & \text { rangkaian }\end{array}$ kegiatan politik yang dinamakan proses kebijakan publik, yang terdiri dari:

a. Identifying problem : demands for government action

b. Formulating policy proposal; Initiation and development public program proposals.

c. Legitimating Policies: Selecting a proposal, building political support for it, and enacting it as law.

d. Implementing Policies : Organizing bureaucracies, providing payments or services, levying taxes.

e. Evaluating policies : Studying programs, evaluating outputs and impacts, suggesting changes and adjustments.

\section{Implementasi Kebijakan}

Implementasi kebijakan merupakan salah satu tahapan yang amat penting dalam suatu kebijakan. Menurut Edwards III (1980:1), policy implementation is the stage of policymaking between establishment of policy...and the concequences of the policy for the people whom it affects.
Implementasi merupakan suatu proses yang dinamis yang melibatkan secara terus menerus usaha-usaha untuk mencari apa yang akan dan dapat dilakukan. Dengan demikian implementasi mengatur kegiatan-kegiatan yang mengarah pada penempatan suatu program kedalam tujuan kebijakan yang diinginkan.

Implementasi kebijakan publik merupakan proses kegiatan yang dilakukan setelah kebijakan ditetapkan/disetujui. Kegiatan ini terletak di antara perumusan kebijakan dan evaluasi kebijakan. Implementasi Kebijakan mengandung logika yang top-down, maksudnya menurunkan menafsirkan alternatif-alternatif yang masih abstrak atau makro menjadi alternatif yang bersifat kongkrit atau mikro.

Implementasi

kebijakan dilaksanakan dengan berbagai aktivitas. Aktivitas Implementasi kebijakan menurut Jones terdiri atas:

a. Organization: The establishment or rearrangement resources,

units, and methods for putting a program into effect.

b. Interpretation: The translation of program language (often contained in a statute) into acceptable and feasible plans and directives

c. Application : the routine provision of services, payments, or other agreed 
upon program objectives or instruments.

(Jones, $1984: 65$ )

Mengacu kepada landasan teori di atas, maka dapat digambarkan kerangka pemikiran sebagai berikut:

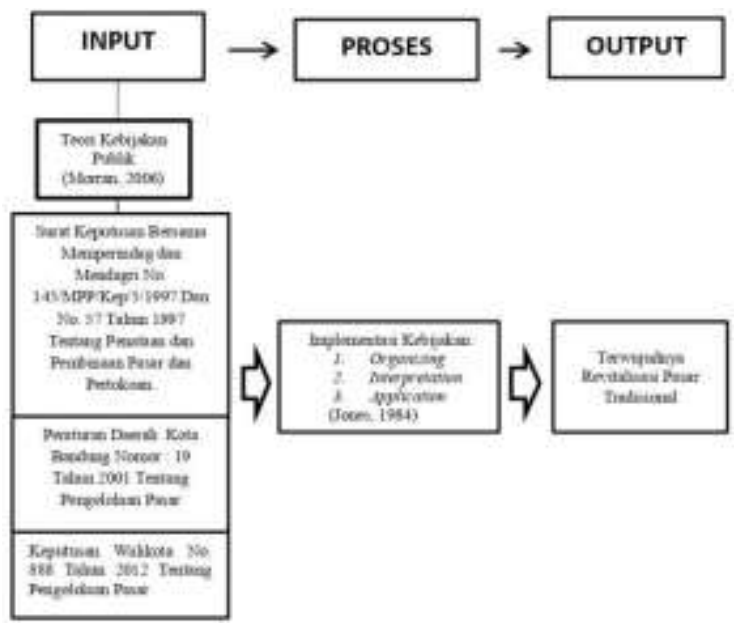

\section{Gambar 1 Model Kerangka Pemikiran}

\section{METODE PENELITIAN}

Penelitian ini menggunakan pendekatan kualitatif dengan metode deskriptif. Pendekatan kualitatif merupakan pendekatan penelitian yang dapat digunakan untuk mengungkapkan dan memahami sesuatu di balik fenomena yang sedikitpun belum diketahui atau juga digunakan untuk mendapatkan wawasan tentang sesuatu yang baru diketahui (Straus dan Corin (2003:5). Dengan metode penelitian deskriptif, penelitian ini bertujuan untuk menganalisis dan menggambarkan fenomena yang terjadi dalam implementasi kebijakan revitalisasi Pasar Tradisional Sarijadi oleh PD. Pasar Bermartabat Kota Bandung.
Teknik Pengumpulan Data

Langkah-langkah pengumpulan data meliputi usaha membatasi penelitian, mengumpulkan informasi melalui observasi dan wawancara, baik yang terstruktur maupun tidak, dokumentasi, materi-materi visual, serta usaha merancang protokol untuk merekam/mencatat informasi (Creswell (2013: 266).

Dalam penelitian kualitatif ini instrumen utamanya adalah peneliti itu sendiri. Peneliti terjun langsung ke lapangan untuk memperoleh data yang dibutuhkan. Adapun teknik pengumlulan data yang dilakukan adalah wawancara mendalam (In Depth Interview), subyek atau informan dalam penelitian ini dipilih dengan menggunakan teknik purposive, yakni informan yang dapat memberikan keterangan dari data yang diperlukan. Menurut ada dua cara yang dapat dilakukan dalam memperoleh informan yaitu (1). Snowballing sampling (2). Key person; Observasi dan Studi Dokumentasi. (Bungin, 2007).

\section{Teknik Analisis Data}

Teknik analisis data dalam penelitian ini menggunakan model analisis interaktif dari Miles M.B, Huberman A.M, Saldana, J (2014: 31-33) yakni metode analisis yang secara terus menerus dilakukan selama penelitian berlangsung, dengan memadukan secara interaktif dan sirkuler tahapan: pengumpulan data (data collection), kondensasi data (data 
condensation), penyajian data (data display), dan penarikan kesimpulan dan verifikasi (conclusion drawing/verification). Jika data yang telah disajikan, diverifikasi dan disimpulkan masih dirasakan masih ada kejanggalan, duplikasi serta ketidaksinkronan, maka tentu dilakukan kembali tahapan kondensasi data.

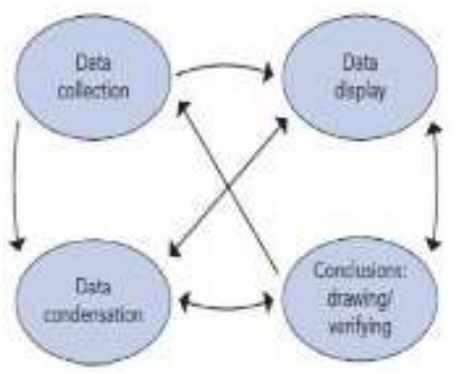

Sumber: Miles M.B, Huberman A.M, Saldana, J. 2014

\section{Gambar 2 Komponen Analisis Data}

\section{Teknik Keabsahan Data}

Agar dapat memperoleh keabsahan data atau kebenaran terhadap hasil penelitian, maka dalam penelitian ini dilakukan langkah-langkah pemeriksaan data seperti yang dikemukakan oleh Lincoln dan Guba dalam Moleong (2011:175), yaitu; derajat kepercayaan (credibility), keteralihan (transferability), kebergantungan (dependability) dan kepastian (confirmability).

\section{HASIL DAN PEMBAHASAN}

Implementasikebijakan dilaksanakan dengan berbagai aktivitas. Aktivitas Implementasi kebijakan menurut Jones terdiri atas Organization, Interpretation, dan Application (Jones, 1984 : 65). Mengacu kepada pendapat Jones tersebut, maka aktivitas implementasi kebijakan revitalisasi Pasar Tradisional Sarijadi Oleh PD. Pasar Bermartabat meliputi:

\section{a. Organization}

Jones (1984) menyatakan bahwa aktivitas pertama dalam implementasi kebijakan adalah pengorganisasian (organization). Aktivitas dalam pengorganisasian meliputi ; pembentukan atau penataan ulang sumber daya, unit kerja, dan metode untuk menjalankan program yang ditetapkan untuk mencapai tujuan kebijakan.

Berdasarkan hasil penelitian mengenai aktivitas pengorganisasian dalam Implementasi Kebijakan Revitalisasi Pasar Sarijadi Oleh PD. Pasar Bermartabat Kota Bandung dapat diketahui sebagai berikut:

\section{Sumber daya}

Sumber daya dalam implementasi kebijakan meliputi sumber daya manusia sebagai penggerak utama organisasi, sumber dana dan fasilitas berupa sarana dan prasarana. Sumber daya bagi suatu organisasi, dinilai sangat penting karena dapat menentukan kualitas organisasi. Tanpa sumber daya yang memadai sesuai dengan kebutuhan organisasi mustahil tujuan organisasi dapat tercapai karena faktor-faktor dalam keberhasilan Implementasi antara lain sumber daya. (Edwards III,1984).

Sumber daya terdiri atas sumber daya manusia untuk mendukung Implementasi Kebijakan Revitalisasi Pasar Tradisional Kota Bandung. Hasil penelitian menunjukkan bahwa sejak tahun 2007 
sumber daya manusia pada PD. Pasar Bermartabat merupakan PNS dari Dinas Pasar Kota Bandung. Berdasarkan Peraturan Daerah Kota Bandung, pada tahun 2012 PNS yang pada umumnya menduduki Jabatan Struktural di PD. Pasar Bermartabat Kota Bandung harus kembali ke Pemerintahan Kota Bandung, sehingga PD. Pasar Bermartabat Kota Bandung harus memiliki pegawai baru (Non PNS) yang direkrut melalui seleksi dan terbuka untuk umum. Siapapun yang menginginkan mengisi jabatan tersebut diberikan kesempatan. Namun hasil seleksi menunjukkan bahwa rata-rata pegawai baru belum memiliki pengalaman seperti pegawai sebelumnya, yang sudah bekerja bertahun-tahun di Dinas Pasar Kota Bandung sehingga sudah memiliki pengalaman dan dapat melaksanakan tugas dengan professional.

Pegawai yang mendukung Implementasi kebijakan Revitalisasi Pasar Tradisional Oleh PD. Pasar Bermartabat Kota Bandung, baik jumlah, kualitas dan kompetensinya belum sesuai dengan kebutuhan sumber daya manusia. (Sambutan Direktur pada pelantikan Pejabat Struktural PD. Pasar Kota Bandung, tahun 2016). Menurut keterangan di atas, jumlah kualitas dan kompetensi sumber daya manusia yang mendukung implementasi kebijakan revitalisasi pasar tradisional olehPD. Pasar Bermartabat Kota Bandung belum sesuai dengan standar kebutuhan. Karena Pengembalian PNS ke Pemerintahan lebih dulu terjadi sebelum proses seleksi dilakukan, maka menyebabkan terjadinya kekosongan dalam jabatan struktural.

Indikator kecukupan pegawai atau staf merupakan sumber daya yang paling esensial dalam mengimplementasikan kebijakan. Sumber daya yang efektif tidak hanya dinilai dari sisi jumlah, namun juga kompetensi atau kecakapan sumber daya manusianya (Subarsono, 2009). Kompetensi sumber daya manusia dalam penelitian ini merupakan kemampuan berupa pengetahuan dan keterampilan yang dimiliki pelaksana kebijakan Revitalisasi Pasar Tradisional oleh PD. Pasar Bermartabat Kota Bandung.

PD. Pasar Bermartabat Kota Bandung, saat ini memiliki jumlah pegawai sebanyak 200 pegawai untuk menangani 40 pasar tradisional di Kota Bandung dan belum didukung oleh kompetensi yang sesuai. (Kepala Sub Bagian Hukum dan Humas PD. Pasar Bermartabat Kota Bandung, 2016).

Kompetensi sumber daya manusia yang mendukung pelaksanaan kebijakan Revitalisasi Pasar Tradisional Sarijadi Kota Bandung belum sesuai dengan kebutuhan, karena pada saat pengisian jabatan oleh pegawai baru tidak sempat pegawai lama yang kompeten dan berpengalaman memberikan transfer knowledge sehingga pengkaderan yang cepat tidak dapat terlaksana.

Berdasarkan hasil penelitian dan pembahasan mengenai sumber daya manusia atau staf dalam mendukung Implementasi Kebijakan Revitalisasi Pasar Tradisional oleh PD Pasar Bermartabat 
Kota Bandung dapat dinyatakan bahwa sumber daya manusia belum sesuai dengan kebutuhan baik jumlah, kualitas maupun kompetensi pegawai.

Di bawah ini tabel menunjukkan jumlah pegawai dan prosentasenya berdasarkan tingkat pendidikan :

Tabel 1

Jumlah dan Komposisi

PegawaiBerdasarkan Tingkat

Pendidikan

\begin{tabular}{clll}
\hline No. & $\begin{array}{l}\text { Tingkat } \\
\text { Pendidikan }\end{array}$ & $\begin{array}{l}\text { Jumla h } \\
\text { (orang) }\end{array}$ & $\begin{array}{l}\text { Prosentase } \\
\text { (terhadap } \\
\text { total) }\end{array}$ \\
\hline 1 & Magister & 4 & $2 \%$ \\
2 & $\begin{array}{l}\text { Sarjana } \\
\text { (S1) }\end{array}$ & 32 & $16 \%$ \\
3 & Sarjana & 8 & $4 \%$ \\
& Muda & & \\
4 & SLTA & 156 & $78 \%$ \\
5 & SLTP & 0 & 0 \\
\hline & Total & 200 & $100 \%$ \\
\hline
\end{tabular}

Sumber: PD. Pasar Bermartabat, data diolah oleh peneliti, 2016

Pada tabel di atas, diketahui bahwa jumlah pegawai PD. Pasar Bermartabat Kota Bandung sebanyak 200 orang. Sebanyak 48 orang bertugas di kantor pusat PD. Pasar Bermartabat dan sebanyak 152 orang bertugas tersebar di 40 pasar di kota Bandung. Dari data tersebut, jumlah pegawai untuk di unit unit masih kurang, rata-rata setiap unit diisi oleh 1 orang Kepala Unit dan 3 orang staf, masih memerlukan pegawai yang kompeten untuk di setiap Unit (UPTD). Tingkat pendidikan yang mayoritas tingkat SLTA, memerlukan banyak pelatihan yang berkaitan dengan tugas pokok dalam rangka meningkatkan mutu dan kompetensinya.

Selain sumber daya manusia, sumber daya lainnya adalah anggaran sebagai sumber dana untuk program dalam Implementasi Kebijakan Revitalisasi Pasar Tradisional oleh PD Pasar Bermartabat Kota Bandung. Besar Anggaran untuk merevitalisasi pasar di Kota Bandung tersedia dari APBD sebesar $82 \mathrm{M}$, berasal dari APBD dengan konsep penyertaan modal.

Anggaran untuk melaksanakan revitalisasi pasar di Kota Bandung adalah sebesar $82 \mathrm{M}$, untuk merevitalisasi Pasar Sarijadi disediakan Anggaran Pembangunan sebesar 1,9 $\mathrm{M}$, namun dalam proses lelang terdapatpengembang yang memberikan penawaran sebesar $1,7 \mathrm{M}$ dan biaya untuk finishing disediakan sebesar 1,5 M. (Direktur PD Pasar Bermartabat, 2017). Nampak bahwa sumber daya berupa anggaran untuk Implementasi Kebijakan Revitalisasi Pasar Tradisional Sarijadi oleh PD. Pasar Bermartabat Kota Bandung cukup tersedia.

Sumber daya fasilitas berupa sarana dan prasarana dalam Implementasi Kebijakan Revitalisasi Pasar Tradisional oleh PD. Pasar Bermartabat Kota Bandung menurut pengamatan peneliti belum memadai. Hal ini dibuktikan oleh data sumber daya fasilitas berupa sarana dan prasarana yang dimiliki PD. Pasar Pasar bermartabat Kota Bandung sebagai berikut :

Tabel 2

Sarana dan Prasarana PD. Pasar 


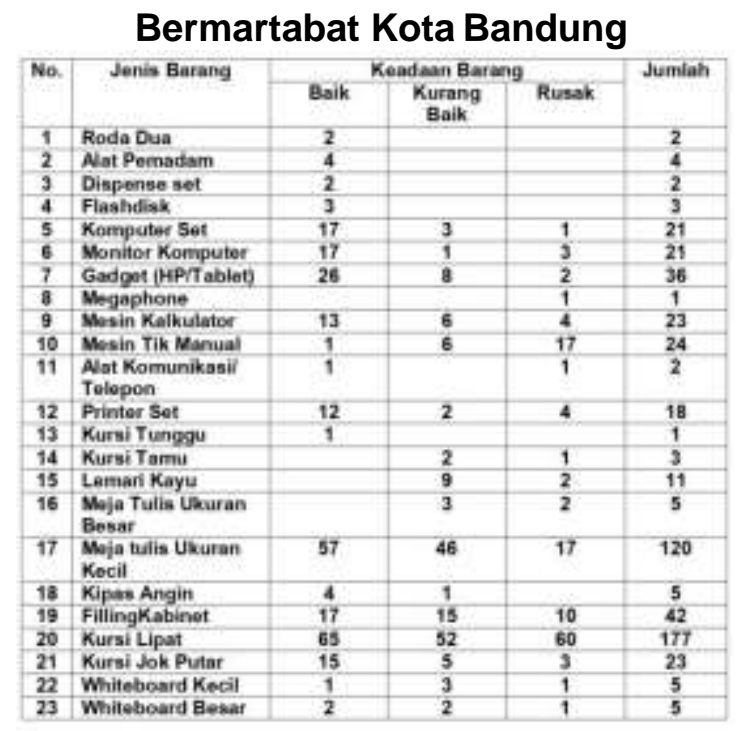

Sumber: https://ppid.bandung.go.id., diunduh Januari 2017

Pada tabel tersebut, terlihat bahwa sarana dan prasarana yang dimiliki PD. Pasar Bermartabat Kota Bandung belum sesuai dengan kebutuhan untuk mengelola 40 Pasar Tradisional termasuk Pasar Sarijadi. Saat ini Sarana dan prasarana yang dimiliki oleh PD. Pasar Bermartabat belum sesuai dengan kebutuhan. (Kepala Sub Bagian Hukum dan Humas PD. Pasar bermartabat Kota Bandung, 2016). Dengan demikian, sumber daya fasilitas berupa sarana dan prasarana untuk mendukung Implementasi Kebijakan Revitalisasi Pasar Tradisional Sarijadi oleh PD. Pasar Bermartabat Kota Bandung belum memadai karena belum sesuai dengan kebutuhan.

\section{Unit Kerja}

Penataan ulang unit kerja dalam Implementasi Kebijakan Revitalisai Pasar Tradisional oleh PD. Pasar Bermartabat Kota Bandung merupakan aktivitas selanjutnya dalam aktivitas pengorganisasian implementasi kebijakan.Seperti telah dijelaskan di atas, saat ini PD. Pasar Bermartabat Kota
Bandung sudah memiliki unit kerja yang jelas, yang tertuang dalam Keputusan Walikota Bandung Nomor 117 tahun 2008 tentang Struktur Organisasi dan Tata Kerja (SOTK) PD. Pasar Bermartabat Kota Bandung. dengan didukung oleh 28 Unit Pelayan Terpadu (UPTD). Untuk menjalankan program revitalisasi Pasar Sarijadi dalam Implementasi kebijakan Revitalisasi Pasar Tradisional oleh PD. Pasar Bermartabat Kota Bandung, unit kerja yang terlibat terutama adalah Direktur Operasional, Kepala Bidang Perencanaan dan Pengembangan Investasi, Kepala Sub Bidang Perencanaan dan Pengembangan, Kepala Sub Bidang Kerjasama dan Investasi, UPTD Pasar Sarijadi dan Pasar Geger Kalong Kota Bandung dan Pihak Pengembang. Meskipun hampir seluruh unit kerja terlibat, namun unit kerja yan langsung terlibat terutama Direktur Operasional, Kepala Bidang Perencanaan dan Pengembangan Investasi, Kepala Sub Bidang Perencanaan dan Pengembangan, Kepala Sub Bidang Kerjasama dan Investasi, UPTD Pasar Sarijadi dan Pasar Geger Kalong Kota Bandung dan Pihak Pengembang. (Kepala Sub Bidang Perencanaan dan Pengembangan, 2017).

Dengan adanya unit kerja yang bertanggung jawab untuk menjalankan program dalam implementasi kebijakan tersebut, diharapkan tujuan kebijakan dapat tercapai sesuai dengan yang diharapkan. Namun apabila dikaitkan dengan sumber daya manusia,keberadaan 
unit kerja yang ada, perlu didukung oleh sumber daya manusia yang memadai. Harus terdapat kesesuaian jumlah, kualitas dan kompetensi dengan kebutuhan. Berdasarkan hasil penelitian dan pembahasan, unit kerja untuk pelaksanaan program dalam implementasi kebijakan revitalisasi pasar tradisional oleh PD. Pasar Bermartabat Kota Bandung sudah ada namun belum didukung oleh sumber daya manusia yangmemadai.

\section{Metode}

Pemilihan metode sebagai bagian aktivitas pengorganisasian dalam Implementasi Kebijakan Revitalisasi Pasar Tradisional oleh PD. Pasar Bermartabat Kota Bandung menentukan keberhasilan pencapai tujuan kebijakan. Program Revitalisasi dalam Implementasi Kebijakan Revitalisasi Pasar Tradisional oleh PD. Pasar Bermartabat Kota Bandung ditetapkan metode pemilihan tema untuk setiap pasar yang akan direvitalisasi, sehingga pasar tradisional yang direvitalisasi merupakan Pasar Tematik. Namun Pasar Tematik belum dituangkan ke dalam bentuk peraturan. Hal ini sudah dicanangkan oleh owner PD. Pasar Bermartabat Kota Bandung, yaitu Walikota Kota Bandung. Maksud pasar tematik ini agar pasar tradisional di Kota Bandung memiliki ciri pasar tersebut, meskipun jenis kebutuhan barang lain tetap ada. Pasar Sarijadi dicanangkan sebagai pasar tematik sayuran organik, mengingat pangsa pasar di daerah Pasar Sarijadi adalah perumahan-perumahan di sekitarnya, di antaranya yaitu perumahan Setra Duta, suatu komplek perumahan kelas atas (elit) yang tentunya membutuhkan sayuran yang segar, berkualitas dan organik, yang dibutuhkan untuk kesehatan. (Kepala Bidang Perencanaan dan Pengembangan PD. Pasar Bermartabat Kota Bandung, 2017).

Metode lain sebagai aktivitas terkait pengorganisasian dalam Implementasi Kebijakan Revitalissi Pasar Tradisional Sarijadi oleh PD. Pasar Bermartabat Kota Bandung adalah program sosialisasi langsung kebijakan kepada para pedagang. Sosialisasi program dalam Implementasi Kebijakan Revitalisasi Pasar Tradisional oleh PD. Pasar Bermartabat Kota Bandung dilaksanakan secara langsung terhadap para pedagang.

Bahkan dilakukan pula studi banding yang diikuti oleh para koordinator pedagang pasar ke Pasar Modern Serpong Kota Tangerang Banten. (Direktur PD. Pasar Bermartabat Kota Bandung, 2017).

Dari pernyataan tersebut di atas, dapat diperoleh keterangan bahwa aktivitas terkait pengorganisasian dalam Implementasi Kebijakan Revitalisasi Pasar Tradisional Sarijadi oleh PD. Pasar Bermartabat Kota Bandung dilaksanakan dengan berbagai metode yang hasilnya diharapkan dapat mendukung tercapainya tujuan Implementasi Kebijakan Revitalisasi Pasar Sarijadi Kota Bandung.

Metode studi banding yang dilaksanakan dalam proses sosialisasi program revitalisasi pada implementasi 
Kebijakan Revitalisasi Pasar Sarijadi oleh PD. Pasar Bermartabat Kota Bandung ke Pasar Modern hasil Program Revitalisasi Pasar dalam implementasi kebijakan di Kota Tangerang dimaksudkan agar pedagang di Pasar Sarijadi mengetahui bagaimana konsep dan realisasi pasar modern yang sehat, bersih dan nyaman dengan penataan ruang dagang yang baik.

Berdasarkan hasil penelitian dan pembahasan dapat dikatakan bahwa metode yang digunakan dalam aktivitas pengorganisasian Implementasi Kebijakan Revitalisasi Pasar Sarijadi oleh PD. Pasar Bermartabat Kota Bandung antara lain meliputi metode penetapan pasar tematik sayuran organik untuk Pasar Sarijadi dan metode sosialisasi kebijakan langsung kepada pedagang serta serta studi banding yang diikuti oleh para pedagang dan pegawai serta Direksi PD. Pasar bermartabat Kota Bandung.

\section{b. Interpretation}

Menurut Jones (1984), aktivitas selanjutnya dalam implementasi kebijakan adalah interpretasi

kebijakan (Interpretation).

Aktivitas dalam interpretasi

kebijakan meliputi kegiatan menterjemahkan program kerja ke dalam rencana kerja/ kegiatan yang dapat dioperasionalkan sehingga keberhasilan implementasi kebijakan melalui program kerja dapat terukur dengan baik. Untuk melaksanakan program revitalisasi dalam Implementasi Kebijakan Revitalisasi
Pasar Tradisional Sarijadi oleh PD. Pasar Bermartabat Kota Bandung didasarkan pada Rencana Strategis yang dibuat secara periodik untuk 4 tahunan. Untuk saat ini Rencana Strategis PD. Pasar Bermartabat Kota Bandung belum tersusun dan ditetapkan, sehingga belum ada pedoman dan arahan untuk pelaksanaan program kerja dan kegiatan PD Pasar Bermartabat Kota Bandung untuk mencapai target ke depan. (Kepala Bidang Perencanaan dan Pengembangan PD. Pasar Bermartabat Kota Bandung, 2017).

Berdasarkan hasil penelitian dan pembahasan, dapat dikatakan bahwa saat ini program kerja dan kegiatan revitalisasi dalam Implementasi Kebijakan Revitalisasi Pasar Tradisional Sarijadi oleh PD. Pasar Bermartabat Kota Bandung belum memiliki pedoman dan arahan pencapaian target ke depan karena belum ditetapkan Rencana Strategis yang baru.

\section{c. Application.}

Menurut Jones (1984), aktivitas terakhir dalam implementasi kebijakan adalah aplikasi (Application). Aktivitas aplikasi dalam implementasi kebijakan meliputi : penyediaan rutin layanan, pembayaran, atau lainnya mengacu tujuan program yang telah disepakati. Pemanfaatan teknologi informasi dalam merevitalisai pasar di Kota Bandung telah dilakukan, demikian halnya untuk Pasar Sarijadi. Saat ini telah dilakukan proses promosi mengunakan internet dengan sistem On-line. Revitalisasi Pasar Sarijadi membangun sebanyak 184 ruang dagang 
yang diperuntukkan terutama untuk pedagang yang setia menjadi pedagang tetap berada di Pasar Sarijadi yang berjumlah 20 orang pedagang. Selanjutnya ditawarkan kepada pedagang ex Pasar Sarjadi yang berada di Pasar Cibogo. Namun tidak menutup kesempatan untuk umum yang benarbenar melakukan perdagangan. Bukan untuk disewakan lagi terhadap orang lain. Penawaran di luar pedagang tetap dilakukan dengan sistem on-line. Terdapat 2 sistem sewa untuk penggunaan hak usaha di Pasar Sarijadi, meliputi Sewa Tahunan dan Sewa 10-20 tahunan. (Kepala Bidang Perencanaan dan Pengembangan PD. Pasar Bermartabat Kota Bandung, 2017). Selain pemanfaatan teknologi informasi untuk promosi, sistem pembayaran retribusipun sudah dilakukan melalui sistem on-line, di mana para pedagang dapat menggunakan hp/android untuk melakukan pembayaran retribusi harian, sehingga mempermudah para pedagang mnyelesaikan kewajibannya. (Kepala UPTD Pasar Sarijadi dan Gegerkalong PD. Pasar Bermartabat Kota Bandung, 2017)

Berdasarkan hasil penelitian dan pembahasan dapat dikatakan bahwa aktivitas aplikasi dalam Implementasi Kebijakan Revitalisasi Pasar Tradisional Sarijadi oleh PD. Pasar Bermartabat Kota Bandung terkait penyediaan layanan sudah menggunakan teknologi informasi untuk layanan pembayaran retribusi dan pengurusan Surat Tanda Tempat Usaha (STTU) untuk para Pedagang, juga promosi untuk penawaran sewa ruang dagang.

\section{KESIMPULAN}

Berdasarkan hasil penelitian dan pembahasan, maka peneliti dapat mengambil kesimpulan sebagai berikut :

1. Implementasi Kebijakan Revitalisasi Pasar belum optimal, dalam hal ini ditandai dengan:

a. Organization yang meliputi :

1) Sumber daya:

a) Sumber daya manusia belum sesuai dengan kebutuhan baik jumlah, kualitas maupun kompetensi pegawai.

b) Sumber dana sudah cukup memadai, yaitu dengan tersedia anggaran untuk Revitalisasi Pasar Sarijadi kurang lebih sebesar 5-6M.

c) Fasilitas sarana dan prasarana belum memadai sehingga belum dapat mendukung implementasi kebijakan revitalisasi pasar.

2) Unit kerja untuk pelaksanaan program dalam implementasi kebijakan revitalisasi pasar tradisional oleh PD. Pasar Bermartabat Kota Bandungsudah ada namun belum didukung oleh sumber daya manusia yang memadai baik dari segi jumlah maupun kualitas.

3) Metode penetapan pasartematik 
sayuran organik untuk Pasar

Sarijadi dan metode sosialisasi kebijakan langsung kepada pedagang serta studi banding yang diikuti oleh para pedagang dan pegawai serta Direksi PD. Pasar bermartabat Kota Bandung.

b. Interpretation

pelaksanaa

nkebijakan belum jelas, karena program kerja yang ada belum memiliki acuan, karena belum dituangkan dalam Renstra.

c. Application pelaksanaan kebijakan telah ada, berupa layanan teknologi informasi teknologi untuk pembayaran retribusi, pengurusan SPTB para pedagang, serta promosi penawaran sewa ruang dagang.

Berdasarkan pada kesimpulan, peneliti memberikan saran sebagai berikut:

a. Perlu segera disusun dan ditetapkan Renstra (Rencana Strategis) untuk periode tahun 2017-2020.

b. Untuk meningkatkan kualitas sumber daya manusia di PD. Pasar Bermartabat Kota Bandung, perlu dilakukan pendidikan dan latihan secara menyeluruh termasuk untuk pimpinan PD. Pasar Bermartabat Kota Bandung, berupa pelatihan tentang manajemen Perusahaan
Daerah (Badan Usaha Daerah khusus pengelolaan pasar).

c. Perlu dilakukan pengukuran untuk keberhasilan pencapaian target pasar.

d. Perlu komitmen terhadap penerapan jenis bisnis baru yang telah ditetapkan.

e. Perlu penambahan sarana dan prasarana, seperti penambahan sarana kendaraan operasional baik kendaraan roda dua maupun roda empat untuk melaksanakan monitoring ke lokasi pasar, penambahan telepon genggam (HP) android untuk melayani sistem pembayaran on-line yang lebih memadai.

\section{DAFTAR PUSTAKA}

Abdullah, 1998. Perkembangan dan Penerapan Studi Implementasi (Action Research and CaseStudies), Jakarta: Lembaga Administrasi Negara.

Creswell, John, W. 1994. Research Design. Qualitative \& Quantitative Approaches. London, New Delhi : Sage Publications.International Educational and ProfesionalPubliher.

Creswell, John, W. 2010. Research Design Pendekatan Kualitatif, Kuantitatif dan Mixed (terjemahan :Achmad Fawaid) Yogyakarta: Pustaka Pelajar.

Danisworo, $\quad$ M, Martokusumo,W, Revitalisasi Kawasan Kota : Sebuah Catatan Dalam Pengembangandan Pemanfaatan Kawasan Kota, Info URDI Vol 13, 2002.

Djafar Zainuddin, dkk, 2012, Peran Strategis Indonesia dalam 
Pembentukan ASEAN \&

Dinamikanya, Jakarta, Penerbit Universitas Indonesia.

Dunn, William N. 2003. Pengantar Studi Penelitian Kebijakan. Jakarta:Bumi Aksara.

Dye, Thomas R, 1992. Understanding Public Policy. New Jersey : Prentice Hall.

Edwards III, George, C ; Sharkansky, Ira, 1978: $\quad$ The Policy Predicamen.Making And Implementing Public Policy. San Francisco W.H.Freeman and Company.

Fornell, C. (1992) A National Customer Satisfaction Barometer: The Swedish Experience. Journal of Marketing, Vol. 56.

Gibson, James L., 1996, Organization, Structure, Processes, Behaviour, Bisniss Publications, Inc.

Gomes, F.C. 1995. Manajemen Sumber Daya Manusia, Yogyakarta, Andi Offset.

Gouillart,Francis, J.; Kelly, James N. , 1995. Transforming The Organization.

Reframing

Corporate Direction, Restructuring the company, Revitalizing The Enterprise, Renewing th

ePeople. United States of America: Mc. Graw Hill. Inc.

Howlett, Michael; Ramesh, M.1995. Studying Public Policy :Policy Cycles and Policy Subsister. Toronto, New York: Oxford: Oxford University Press.

Harefa, Mandala. 2008. Kebijakan Usaha Kecil dan Menengah dan Peranannya dalam Perekonomian.Kajian 4 (2): 2955. [33]

Hutomo," Kebijakan Pengembangan Dan Penguatan UMKM Berbasis
Kerjasama Kemitraan Dengan Pola CSR Sebagai Strategi Peningkatan Peran Pemerintah dan Perusahaan untuk Menjaga Eksistensi UMKM Islami, Irfan. 1997. Prinsip-prinsip Perumusan Negara.Jakarta: Bumi Aksara.

http://infobandung.co.id/pasar-sarijadimulai-dibangun

http://nugrohodidik.blogspot.co.id/201 2/12/implementasi-kebijakanpublik.html

https://ppid.bandung.go.id/2015

http://www.kemendag.go.id/2016

http://www.koran-sindo.com/2015

Jones, Charles, O, 1984. An Introduction to the Study of Publick Policy; Third Edition. Monterey California Brooks /Cole Publishing Company.

KeputusanWalikota Bandung Nomor 511.2/Kep.155-Huk/2006 tentang Revitalisasi Pasar.

Keputusan Walikota Bandung Nomor 888 Tahun 2012 tentang Peraturan Walikota Bandung No. 888 Tahun 2012 Tentang Petunjuk Teknis Pelaksanaan Peraturan Daerah Kota Bandung No. 4 Tahun 2011 Tentang Penataan dan Pembinaan Pedagang Kaki Lima.

Keputusan Bersama Memperindag dan Mendagri Nomor Nomor 57 tahun 1997 tentang Penataan dan Pembinaan Pasar dan Pertokoan.

Lasswell, Harold, D., \& Kaplan, Abraham, 1970. Power and Society. Yale University Press., New Haven.

Mardi Yatno Utomo, 2000, Pemberdayaan Masyarakat Dalam Bidang Ekonomi, Tinjauan Teoritis Dan Implementasi, Jakarta: Bappenas

Moleong. 2011. Metode Penelitian Kualitatif, Bandung,, PT Remaja 
Rosdakaya.

Moran, Michael, et al 2006, The Oxford Handbook of Public Policy, New

York: Oxford University

Press Inc.

Nugroho, R. 2014. Public Policy; Teori, Manajemen, Dinamika, Analisis, Konvergensi dan Kimia Kebijakan, PT Elex Media Komputindo,Jakarta.

Pal, Leslie, A.1992 Public Policy Analy is. An Introduction. Ontario: A Division of Thomson Canada, Limited.

Pasolong, Harbani, 2007, Teori Administrasi Publik, Bandung, Alfabeta.

Parsons, Wayne, 1995. Public Policy, . An Introduction to Theory and Practice of Policy Analysis. Cheltonham U.K. Edward Elgar Publishing. Inc.

Peraturan Daerah Kota Bandung No. 4 Tahun 2011 Tentang Penataan dan Pembinaan Pedagang Kaki Lima

Peraturan Walikota Bandung No. 571 Tahun 2014 Tentang Perubahan Atas Peraturan Walikota BandungNo. 888 Tahun 2012 Tentang Petunjuk Teknis PelaksanaanPeraturan Daerah Kota Bandung No. 4 Tahun 2011 Tentang Penataan dan Pembinaan Pedagang Kaki Lima.

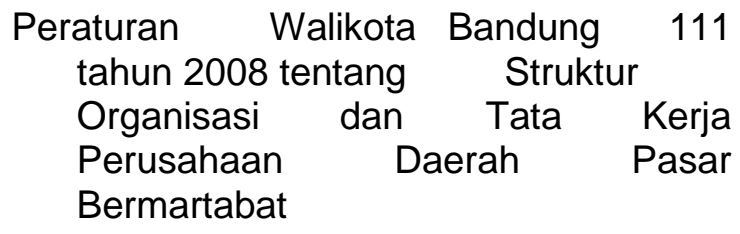

Peraturan Walikota Bandung No. 888 Tahun 2012 Tentang Petunjuk Teknis Pelaksanaan Peraturan Daerah Kota Bandung No. 4 Tahun 2011 Tentang Penataan dan Pembinaan Pedagang Kaki Lima.

Peraturan Daerah Kota Bandung Nomor : 19 Tahun 2001, tentang Pengelolaan Pasar.
Pressman, J.L and Wildausky, 1973. Implementation. Barkley and Los Angeles University of California Press.

Purba Radiks, 1990, Mengenal Praktek Bisnis, Jakarta, Pustaka Binaman Pressindo.

Siahaan,Rambe.A. Mahidin. 2006. Manajemen Pengawas Pendidikan, Ciputat, Quantum Teaching.

Simon, Christopher, A. 2007; Public Policy Prefferences and Outcomes. Nevada Pearson

Education. Inc.

Solihin, W.A. 2001.Evaluasi Kebijakan Publik. UMM Press, Malang

Solihin, W.A. 2008.Pengantar Analisis Kebijakan Publik. UMM Press, Malang

Subarsono, AG, 2005. Analisis Kebijakan Publik: Konsep, Teori dan Aplikasi. Yogyakarta: Pustaka Pelajar.

Sugiyono, 2012, Metode Penelitian Kuantitatif Kualitatif Dan R\&D, Bandung, Alfabeta.

Surat Keputusan Bersama Memperindag dan Mendagri Nomor 145/MPP/Kep/5/1997 tentang Penataan dan Pembinaan Pasar dan Pertokoan.

Tambunan, Tulus, 2009. UMKM Di Indonesia, Jakarta: Ghalia Indonesia.

Tangkilisan, Nogi S., Hessel, 2003. Evaluasi Kebijakan Publik: Penjelasan, Analisis \& Transformasi Pikiran Nagel, Penerbit Balairung \& Co, Yogyakarta.

Tjiptono, Fandy. (2004). Strategi Pemasaran, Edisi 2, Penerbit Andi, Yogyakarta.

Wibawa, Samodra. 1994.Evaluasi Kebijakan Publik. Jakarta, Raja Grafindo Persada.

Zeithaml Valarie A, Parasuraman and 
Berry.L. Leonard, Delivering Quality Service, Balancing Customer Perception and Expectations, The Free Press. Toronto Canada.

www.kompasiana.com, 2015

www.pendidikanekonomi.com.2012 